DOI: http://dx.doi.org/10.18203/2320-1770.ijrcog20192461

Original Research Article

\title{
Serum urocortin in preterm labor is it an effective biomarker?
}

\author{
Nancy Mohamed Ali Rund*
}

Department of Obstetrics and Gynaecology, Ain Shams University, Cairo, Egypt

Received: 07 April 2019

Accepted: 06 May 2019

\section{*Correspondence:}

Dr. Nancy Mohamed Ali Rund,

E-mail: nancyrund123@gmail.com

Copyright: (c) the author(s), publisher and licensee Medip Academy. This is an open-access article distributed under the terms of the Creative Commons Attribution Non-Commercial License, which permits unrestricted non-commercial use, distribution, and reproduction in any medium, provided the original work is properly cited.

\begin{abstract}
Background: Preterm labor classically defined as delivery before completed 37 gestational weeks. Urocortin a biomarker that have raised recent research interest is a 40-amino acid neuropeptide related to the corticotrophinreleasing factor molecular family. Interestingly urocortin is produced by gestational tissue such as amnion and chorion predictability of preterm labor by biomarker assay could enhance management levels particularly in cases of preterm labor that are considered a frequent clinical scenario in obstetric practice. Aim of the study was to assess and evaluate the serum levels of urocortin predictability capacity in cases that develop preterm labor.

Methods: The current research clinical trial was conducted in a prospective way there was two research groups 60 study subjects had threatened preterm labor and 60 normal research study subjects that delivered at term. Comparative analysis was performed for urocortin assay conducted in both research groups in correlation to gathered clinical data obtained from both research groups.

Results: Receiver operating characteristic curve (ROC) between preterm and term delivery research groups as regards plasma urocortin level $(\mathrm{pg} / \mathrm{ml})$ as a predictor of pre term delivery showing that a cut-off point level $>101.3 \mathrm{pg} / \mathrm{ml}$ in which statistical sensitivity $=88.33 \%$, statistical specificity $=75 \%$, positive predictive value $=77.9$, negative predictive value $=86.5$.

Conclusions: This research finding reveal that maternal serum urocortin is an effective biomarker in predictability of preterm labor; however future research studies should be multicentric in fashion putting in consideration the racial and ethnic differences besides the impact of BMI on maternal serum urocortin indices.
\end{abstract}

Keywords: Biomarker, Myometrial contractility, Preterm labor, Urocortin, Uteroplacental perfusion

\section{INTRODUCTION}

Preterm labor classically defined as delivery before completed 37 gestational weeks, preterm labor and prematurity issues are a frequent clinical scenario faced in every day obstetric practice that obligates the researchers all over the globe to investigate predictability tools on various basis such as sonographic, clinical, and biochemical markers. ${ }^{1,2}$

Biomarkers are extensively investigated over the past two decades with variations in sensitivity and specificity levels, however the perfect universal biomarker is still not apparent for routine clinical practice., , $^{3,4}$
Urocortin a biomarker that have raised recent research interest is a 40 amino acid neuropeptide related to the corticotrophin-releasing factor molecular family. ${ }^{5}$ Interestingly urocortin is produced by gestational tissue such as amnion and chorion; furthermore it could be assayed from maternal and fetal circulatory systems that could be implemented in clinical correlation to preterm labor impending clinical presentation. ${ }^{6}$

Urocortin have stable levels all over the three gestational trimesters and vary according to uterine activity quiescence and contractility and was observed to be increasing in preterm delivery cases particularly originating in large amounts from myometrial cells. ${ }^{7}$ At 
molecular and cellular levels urocortin triggers the myometrial responsiveness to prostaglandins aiding in propagation and augmentation of the physiological process of delivery. ${ }^{8}$

On the other hand, in post term pregnancies it was observed, revealed, and displayed that serum levels of urocortin are reduced.9 All previous research findings denote that it could be possibly be implemented as a promising biomarker in early detection and predictability of preterm labor. ${ }^{10}$

The aim was to assess and evaluate the serum levels of urocortin predictable capacity in cases that develop preterm labor.

\section{METHODS}

This study was carried out in Saudi Arabia, in Jeddah at a private hospital (Bugshan Hospital) for a period starting from January 2011 to December 2018.

This research clinical trial is a prospective study in which there were two research groups 60 study subjects who had threatened preterm labor and 60 normal research study subjects that delivered at term all research study subjects were subjected to full clinical history, examination and other routine investigations besides the urocortin assay. Inclusive research criteria involved the following singleton gestations, presenting with threatened preterm labor from 28 till 36 gestational weeks. Exclusive research criteria involved the following cases with multi fetal gestations, fetal distress, DM, placental abruption, preeclampsia, IUGR, Fetal congenital anomalies, above $5 \mathrm{~cm}$ cervical dilatation, and infectious clinical signs.

\section{Urocortin assay}

Performed by radioimmunoassay having a sensitivity of around $50 \mathrm{pg} / \mathrm{ml}$ with intraassay and interassay variations of 6 and $8 \%$, consecutively.

\section{Statistical analysis}

Data were collected, revised, coded, and entered to the Statistical Package for Social Science (IBM SPSS) version 23. Quantitative data were presented as mean, standard deviations and ranges when parametric and median with inter-quartile range when non parametric, also qualitative variables were presented as number and percentages. The comparison between two groups regarding qualitative data was done by using Chi-square test, also groups with quantitative data and parametric distribution was done by using Independent t-test while with non-parametric data were compared using MannWhitney test. Spearman correlation coefficients were used to assess the correlation of plasma Urocortin level with gestational age (weeks) and with interval between admission and delivery. Receiver operating characteristic curve (ROC) was used to assess the sensitivity, specificity, positive predictive value (PPV), negative predictive value (NPV) and area under curve (AUC) of plasma Urocortin level as a predictor for preterm labor and interval between admission and delivery. The confidence interval was set to $95 \%$ and the margin of error accepted was set to $5 \%$. So, the p-value $<0.05$ was considered significant.

\section{RESULTS}

Table 1 reveals and displays the comparative analysis of research data of the studied research groups in which age, parity, rupture of membranes, chorioamnionitis, gestational age at sampling there was no statistical significant difference between both research groups term and preterm delivery $(\mathrm{p}=0.163,0.927,0.832,0.250,0.257$ consecutively). On the other hand, gestational age at time of delivery, birth weight, plasma urocortin levels were statistically highly significantly different between both research groups $(\mathrm{p}<0.001)$.

Figure 1 reveal and display that serum levels of plasma Urocortin were statistically significantly higher in preterm research group $(\mathrm{p}<0.001)$ term delivery research group versus preterm delivery research group Median $(\mathrm{IQR})=93.95(71.10-102.15) \mathrm{pg} / \mathrm{ml}$ versus 124.1 (110.99146.76) $\mathrm{pg} / \mathrm{ml}$.

Table 2 reveals receiver operating characteristic curve (ROC) between preterm and term delivery research groups as regards plasma urocortin level $(\mathrm{pg} / \mathrm{ml})$ as a predictor of pre term delivery showing that a cutoff point level $>101.3 \mathrm{pg} / \mathrm{ml}$ in which statistical sensitivity $=88.33 \%$, statistical specificity $=75 \%$, positive predictive value $=77.9$, negative predictive value $=86.5$.

Table 3 reveals and displays that there was no statistical significant difference between research study subjects delivered within one week of admission $(n=47)$ and research study subjects who delivered more than one week after admission $(n=13)$ as regards age, parity, ruprure of memebranes, chorioamnionitis, gestational age at sampling, gestational age at time of delivery ( $\mathrm{p}$ values= $0.103,0.217,0.890,0.899,0.069$ and 0.082 consecutively whereas there was highly statistical significant difference between both compared research categorial groups as regards interval between admission, birth weight, plasma urcortin (pg/ml) ( $\mathrm{p}<0.001,0.001,<0.001$ consecutively).

Table 4 reveal and display Receiver operating characteristic curve (ROC) between preterm delivered within 7 days of admission and those who delivered more than 7 days of admission in which cut off point level of serum urcortin $>104.8 \mathrm{pg} / \mathrm{ml}$ IN which area under the curve $=0.984$, statistical sensitivity $=97.87 \%$, statistical specificity $=92.31 \%$, positive predictive value $=97.9$, negative predictive value $=92.3$. 
Table 1: Comparison between term delivery and preterm delivery regarding the studied parameters $(n=60)$.

\begin{tabular}{|c|c|c|c|c|c|}
\hline & Term delivery & Preterm delivery & Test value & P value & Sig \\
\hline \multicolumn{6}{|l|}{ Age } \\
\hline Mean \pm SD & $27.95 \pm 2.87$ & $28.73 \pm 3.21$ & \multirow[t]{2}{*}{$1.403 \bullet$} & \multirow[t]{2}{*}{0.163} & \multirow[t]{2}{*}{ NS } \\
\hline Range & $23-34$ & $21-36$ & & & \\
\hline \multicolumn{3}{|l|}{ Parity } & \multirow{3}{*}{$0.051^{*}$} & \multirow{3}{*}{0.927} & \multirow{3}{*}{ NS } \\
\hline Median (IQR) & $1(1-2)$ & $2(0-2)$ & & & \\
\hline Range & $0-3$ & $0-3$ & & & \\
\hline \multicolumn{3}{|c|}{ Rupture of membrane } & \multirow{3}{*}{$0.045^{*}$} & \multirow{3}{*}{0.832} & \multirow{3}{*}{ NS } \\
\hline Negative & $46(76.7 \%)$ & $45(75.0 \%)$ & & & \\
\hline Positive & $14(23.3 \%)$ & $15(25.0 \%)$ & & & \\
\hline \multicolumn{3}{|c|}{ Chorioamnionitis } & \multirow{3}{*}{$1.319^{*}$} & \multirow{3}{*}{0.250} & \multirow{3}{*}{ NS } \\
\hline Negative & $42(70.0 \%)$ & $36(60.0 \%)$ & & & \\
\hline Positive & $18(30.0 \%)$ & $24(40.0 \%)$ & & & \\
\hline \multicolumn{3}{|l|}{ GA at sampling } & \multirow{3}{*}{$1.139 \bullet$} & \multirow{3}{*}{0.257} & \multirow{3}{*}{ NS } \\
\hline Mean \pm SD & $31.2 \pm 1.2$ & $30.9 \pm 1.65$ & & & \\
\hline Range & $30-33$ & $29-34$ & & & \\
\hline \multicolumn{3}{|l|}{ GA at delivery } & \multirow{3}{*}{$34.910 \bullet$} & \multirow{3}{*}{$<0.001$} & \multirow{3}{*}{ HS } \\
\hline Mean \pm SD & $38.9 \pm 0.45$ & $32.7 \pm 1.3$ & & & \\
\hline Range & $37.3-40.5$ & $30.6-34.5$ & & & \\
\hline \multicolumn{3}{|l|}{ Birth weight } & \multirow{3}{*}{$56.133 \bullet$} & \multirow{3}{*}{$<0.001$} & \multirow{3}{*}{ HS } \\
\hline Mean \pm SD & $3367.4 \pm 125.2$ & $1967.3 \pm 147.15$ & & & \\
\hline Range & $2815-3750$ & $1690-2540$ & & & \\
\hline \multicolumn{3}{|c|}{ Plasma Urocortin (pg/ml) } & \multirow{3}{*}{$7.023^{*}$} & \multirow{3}{*}{$<0.001$} & \multirow{3}{*}{ HS } \\
\hline Median (IQR) & $93.95(71.10-102.15)$ & $124.1(110.99-146.76)$ & & & \\
\hline Range & $50.4-160.7$ & $90.18-172.3$ & & & \\
\hline
\end{tabular}

GA: Gestational age; NS: Non significant; HS: Highly significant; $\bullet:$ Independent t-test; ${ }^{*}$ : Mann-Whitney test; *: Chi-square test.

Table 2: Receiver operating characteristic curve (ROC) between preterm and term delivery research groups as regards plasma Urocortin level.

\begin{tabular}{|c|c|c|c|c|c|}
\hline Cut off point & $\begin{array}{l}\text { AUC } \\
(95 \% \text { CI })\end{array}$ & $\begin{array}{l}\text { Sensitivity } \\
(95 \% \mathrm{CI})\end{array}$ & $\begin{array}{l}\text { Specificity } \\
\text { (95\% CI) }\end{array}$ & $\begin{array}{l}+\mathrm{PV} \\
(95 \% \mathrm{CI})\end{array}$ & $\begin{array}{l}-\mathrm{PV} \\
(95 \% \mathrm{CI})\end{array}$ \\
\hline$>101.3$ & $\begin{array}{l}0.878 \\
(0.806 \text { to } 0.931)\end{array}$ & $\begin{array}{l}88.33 \\
(77.4-95.2)\end{array}$ & $\begin{array}{l}75.00 \\
(62.1-85.3)\end{array}$ & $\begin{array}{l}77.9 \\
(66.2-87.1)\end{array}$ & $\begin{array}{l}86.5 \\
(74.2-94.4)\end{array}$ \\
\hline
\end{tabular}

Table 3: Comparison between research study subjects who delivered within one week of admission and those who delivered more than one week of admission as regards the studied research parameters.

\begin{tabular}{|c|c|c|c|c|c|}
\hline & $\begin{array}{l}\text { Delivered within one } \\
\text { week of admission } \\
\mathrm{n}=47\end{array}$ & $\begin{array}{l}\text { Delivered more than one } \\
\text { week of admission } \\
n=13\end{array}$ & Test value & $P$ value & Sig. \\
\hline Age & & & \multirow{2}{*}{$1.658 \bullet$} & \multirow{2}{*}{0.103} & \multirow{2}{*}{ NS } \\
\hline Mean \pm SD & $27.98 \pm 2.58$ & $29.48 \pm 3.84$ & & & \\
\hline Parity & & & \multirow{2}{*}{$1.322^{\ddagger}$} & \multirow{2}{*}{0.217} & \multirow{2}{*}{ NS } \\
\hline Median (IQR) & $1(0-2)$ & $2(1-3)$ & & & \\
\hline Rupture of membrane & & & \multirow{3}{*}{$0.019 *$} & \multirow{3}{*}{0.890} & \multirow{3}{*}{ NS } \\
\hline Negative & $37(78.7 \%)$ & $10(76.9 \%)$ & & & \\
\hline Positive & $10(21.3 \%)$ & $3(23.1 \%)$ & & & \\
\hline Chorioamnionitis & & & \multirow{3}{*}{$0.016^{*}$} & \multirow{3}{*}{0.899} & \multirow{3}{*}{ NS } \\
\hline Negative & $28(59.57 \%)$ & $8(61.54 \%)$ & & & \\
\hline Positive & $19(40.43 \%)$ & $5(38.46 \%)$ & & & \\
\hline GA at sampling & & & \multirow{2}{*}{1.85} & \multirow{2}{*}{0.069} & \multirow{2}{*}{ NS } \\
\hline Mean \pm SD & $31.45 \pm 2.02$ & $30.35 \pm 1.28$ & & & \\
\hline Interval between admission & $4.74 \pm 1.64$ & $13.15 \pm 1.57$ & $16.542 \bullet$ & $<0.001$ & HS \\
\hline
\end{tabular}




\begin{tabular}{|c|c|c|c|c|c|}
\hline & $\begin{array}{l}\text { Delivered within one } \\
\text { week of admission } \\
n=47\end{array}$ & $\begin{array}{l}\text { Delivered more than one } \\
\text { week of admission } \\
n=13\end{array}$ & Test value & P value & Sig. \\
\hline \multicolumn{6}{|l|}{ and delivery } \\
\hline \multicolumn{3}{|l|}{ GA at delivery } & \multirow{2}{*}{$1.770 \bullet$} & \multirow{2}{*}{0.082} & \multirow{2}{*}{ NS } \\
\hline Mean \pm SD & $32.38 \pm 1.01$ & $33.02 \pm 1.59$ & & & \\
\hline \multicolumn{3}{|l|}{ Birth weight } & \multirow{2}{*}{$3.355 \bullet$} & \multirow{2}{*}{0.001} & \multirow{2}{*}{ HS } \\
\hline Mean \pm SD & $1894.3 \pm 132.15$ & $2040.3 \pm 162.15$ & & & \\
\hline \multicolumn{3}{|c|}{ Plasma Urocortin (pg/mL) } & \multirow{3}{*}{$5.482^{\ddagger}$} & \multirow{3}{*}{$<0.001$} & \multirow{3}{*}{ HS } \\
\hline Median (IQR) & $135.7(121.6-150.6)$ & $99.4(96.4-103.8)$ & & & \\
\hline Range & $102.27-172.3$ & $90.18-115.8$ & & & \\
\hline
\end{tabular}

GA: Gestational age; NS: Non significant; HS: Highly significant. •: Independent t-test; *: Mann-Whitney test; *: Chi-square test.

Table 4: Receiver operating characteristic curve (ROC) between preterm delivered within 7 days of admission and those who delivered more than 7 days of admission.

\begin{tabular}{|c|c|c|c|c|c|}
\hline Cut off point & $\begin{array}{l}\text { AUC } \\
(95 \% \mathrm{CI})\end{array}$ & $\begin{array}{l}\text { Sensitivity } \\
(95 \% \mathrm{CI})\end{array}$ & $\begin{array}{l}\text { Specificity } \\
(95 \% \text { CI) }\end{array}$ & $\begin{array}{l}+\mathrm{PV} \\
(95 \% \mathrm{CI})\end{array}$ & $\begin{array}{l}-\mathrm{PV} \\
(95 \% \mathrm{CI})\end{array}$ \\
\hline$>104.8$ & $\begin{array}{l}0.984 \\
(0.911 \text { to } 1.000)\end{array}$ & $\begin{array}{l}97.87 \\
(88.7-99.9)\end{array}$ & $\begin{array}{l}92.31 \\
(64.0-99.8)\end{array}$ & $\begin{array}{l}97.9 \\
(88.5-99.9)\end{array}$ & $\begin{array}{l}92.3 \\
(64.0-99.8)\end{array}$ \\
\hline
\end{tabular}

Table 5: Spearman correlation coefficients for the Plasma Urocortin level.

\begin{tabular}{|lll|}
\hline & Plasma Urocortin $(\mathrm{pg} / \mathrm{mL})$ & \\
\hline Interval between admission and delivery & $\mathbf{r}$ & P value \\
\hline GA (weeks) & -0.596 & $<0.001(\mathrm{HS})$ \\
\hline
\end{tabular}

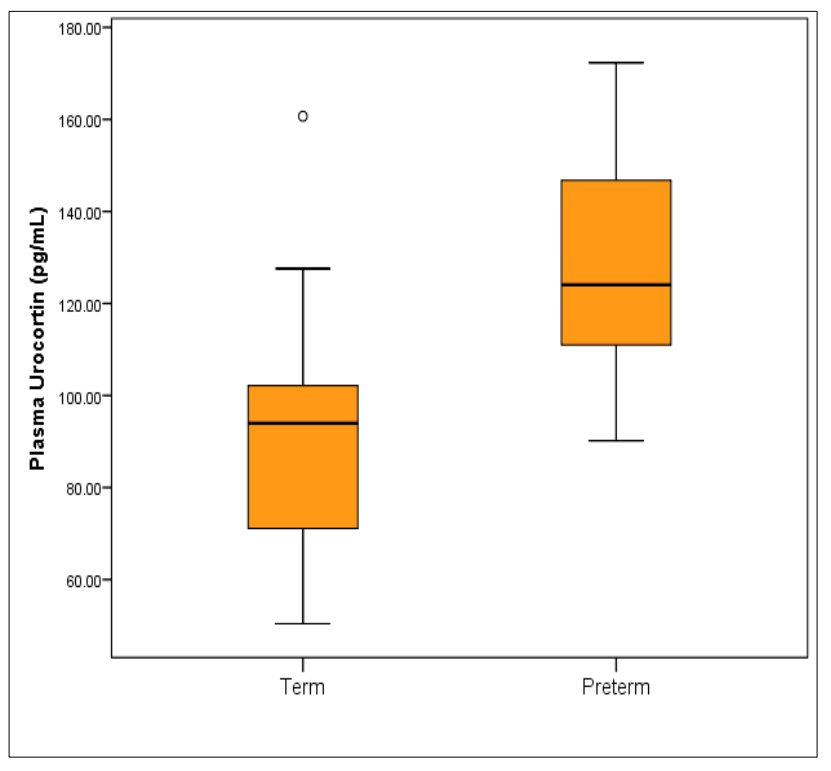

Figure 1: Plasma urocortin level $(\mathrm{pg} / \mathrm{ml})$ in term and preterm delivery research groups.

Table 5 reveal and display that by Spearman correlation coefficient statistical analysis that plasma urocortin level is highly statistically significant as regards interval between admission and delivery and gestational age (weeks) $\mathrm{p}<0.001$.

\section{DISCUSSION}

The research evidence obtained by histopathological research studies revealed that urocortin present in maternal circulation is chiefly from fetal tissues interestingly increasing the research debate and interest about the cross talk between the fetal and maternal systems in maintaining uterine quiescence besides trigger and upkeep of preterm labor. ${ }^{11}$

Prior Research findings reveal and display that preterm labor could be correlated with reduction in vascular resistance of fetal cerebral circulatory blood flow; besides fetal urocortin secretory pattern is linked with uteroplacental blood perfusion pattern. ${ }^{12}$ In addition, urocortin has shown to have considerable and persistent hemodynamic impact against hypoxia in experimental research animals. ${ }^{3}$ Therefore, it is reasonable to consider that urocortin secretion could safeguard the fetus from the hypoxic insult sequelae..$^{5}$

This research study findings revealed and displayed that by comparative statistical analysis of research data of the studied research groups in which age,parity, rupture of membranes, chorioamnionitis, gestational age at sampling there was no statistical significant difference between both research groups term and preterm delivery ( $\mathrm{p}=0.163,0.927,0.832,0.250,0.257$ consecutively). On the other hand, gestational age at time of delivery, birth 
weight, plasma Urocortin levels were statistically highly significantly different between both research groups $(p<0.001)$. Furthermore receiver operating characteristic curve (ROC) between preterm and term delivery research groups as regards plasma Urocortin level $(\mathrm{pg} / \mathrm{ml})$ as a predictor of pre term delivery showing that a cutoff point level $>101.3 \mathrm{pg} / \mathrm{ml}$ in which statistical sensitivity $=88.33 \%$, statistical specificity $=75 \%$, positive predictive value $=77.9$, negative predictive value $=86.5$.

Additionally our research study findings revealed and displayed that there was no statistical significant difference between research study subjects delivered within one week of admission $(n=47)$ and those who delivered more than one week after admission $(n=13)$ as regards age, parity, rupture of membranes, chorioamnionitis, gestational age at sampling, gestational age at time of delivery ( $\mathrm{p}$ values $=0.103,0.217,0.890$, $0.899,0.069$ and 0.082 consecutively. Whereas there was highly statistically significant difference between both compared research categorical groups as regards interval between admission, birth weight, plasma urocortin $(\mathrm{pg} / \mathrm{ml})(\mathrm{p}<0.001,0.001,<0.001$ consecutively $)$.

Finally Receiver operating characteristic curve (ROC) between preterm delivered within 7 days of admission and those who delivered more than 7 days of admission in which cut off point level of serum urocortin $>104.8$ $\mathrm{pg} / \mathrm{ml}$ IN which area under the curve $=0.984$, statistical sensitivity $=97.87 \%$, statistical specificity $=92.31 \%$, positive predictive value $=97.9$, negative predictive value $=92.3$, Spearman correlation coefficient statistical analysis have shown that plasma urocortin level is highly statistically significant as regards interval between admission and delivery and gestational age (weeks) $\mathrm{p}<0.001$.

A prior research study similar to the current research in methodology and approach have revealed and displayed that cases having threatened preterm labor have raised plasma levels of urocortin another research team of investigators have assayed the serum urocortin levels displaying its significantly raised levels in preterm labor cases and cases with impending delivery issues. ${ }^{1,4}$ Those research findings could be justified by the fact urocortin peptide triggers at cellular and molecular levels the myometrial contractility as displayed by in vitro research studies furthermore research groups of investigators priory compared and contrasted between serum urocortin in full term and preterm deliveries revealing and displaying the considerable rise of its levels even at the time of full term delivery. ${ }^{13}$

A prior cohort research study performed on pregnant cases at 28-36 gestational weeks having spontaneous preterm labor. Serum urocortin was assayed from all research study subjects. The cases recruited for the study were followed up till time of delivery and serum level of urocortin were statistically compared between cases having preterm delivery and those who delivered at term
(37 gestational weeks). The research team revealed and displayed the following research results in which from the One hundred and sixty research study subjects: One hundred and forty-eight $(92.5 \%)$ of the cases had preterm delivery. Mean serum level of urocortin within the preterm delivery research group have been greater than in the Term research group, but not in a statistically significant fashion $(392.6 \pm 29.23$ versus 113.2 \pm 11.0 . $\mathrm{pg} / \mathrm{mL}$, consecutively, $\mathrm{p}=0.252$ ). Area under the ROC curve $=0.6$, revealing that serum urocortin assay is not suitable appropriate for predictability preterm labor those research findings contradict with our research study findings. ${ }^{2,7,11}$

\section{CONCLUSION}

The current research findings reveal that maternal serum urocortin is an effective biomarker in predictability of preterm labor, however future research studies should be multicentric in fashion putting in consideration the racial and ethnic differences besides the impact of BMI on maternal serum urocrtin indices.

Furthermore, future research studies should be implemented with larger sample sizes that could aid in future clinical guideline implementation that would enhance management protocols in those cases.

\section{Funding: No funding sources}

Conflict of interest: None declared

Ethical approval: The study was approved by the Institutional Ethics Committee

\section{REFERENCES}

1. Kashanian M, Bahasadri S, Ghasemi A, Bathaee S. Value of serum urocortin concentration in the prediction of preterm birth. J Obstet Gynaecol Res. 2013;39(1):26-30.

2. Romero R, Dey SK, Fisher SJ. Preterm labor: one syndrome, many causes. Science. 2014;345:760-5.

3. Platt MJ. Outcomes in preterm infants. Public Health. 2014;128:399-403.

4. Feldman K, Woolcott C, O'Connell C, Jangaard K. Neonatal outcomes in spontaneous versus obstetrically indicated late preterm births in a nova scotia population. J Obstet Gynaecol Can. 2012;34:1158-66.

5. World Health Organization: Born Too Soon: The Global Action Report on Preterm Birth. Geneva: WHO Press; 2012.

6. Moroz LA, Simhan HN. Rate of sonographic cervical shortening and biologic pathways of spontaneous preterm birth. Am J Obstet Gynecol. 2014;210:555.e1-5.

7. Pawelec M, Pałczyński B, Krzemieniewska J, Karmowski M, Koryś J, Lątkowski K, et al. Initiation of preterm labor. Adv Clin Exp Med. $2013 ; 22: 283-8$. 
8. Kageyama K, Teui K, Tamasawa N, Suda T. Regulation and roles of urocortins in the vascular system. Int J Endocrinol 2012; 2012:873723.

9. Karaer A, Celik E, Celik O, Simsek OY, Ozerol İH, Yılmaz E, Turkcuoglu I, Duz SA: Amniotic fluid urocortin-1 concentrations for the prediction of preterm delivery. J Obstet Gynaecol Res 2013;39:1236-41.

10. Brown H, Speechley K, Macnab J, Natale R, Campbell M: Biological determinants of spontaneous late preterm and early term birth: a retrospective cohort study. BJOG. 2015;122:491-9.

11. Florio P, Linton EA, Torricelli M, Faldini E, Reis FM, Imperatore A. Prediction of preterm delivery based on maternal plasma urocortin. J Clin Endocrinol Metab. 2007;92:4734-7.
12. Florio P, Torricelli M, Galleri L, De Falco G, Leucci E, Calonaci G. High fetal urocortin levels at term and preterm labor. J Clin Endocrinol Metab. 2005;90:5361-5.

13. Torricelli M, Ignacchiti E, Giovannelli A, Merola A, Scarpetti E, Calonaci G. Maternal plasma corticotropinreleasing factor and urocortin levels in post-term pregnancies. Eur J Endocrinol. 2006;154:281-5.

Cite this article as: Rund NMA. Serum urocortin in preterm labor is it an effective biomarker? Int $\mathrm{J}$ Reprod Contracept Obstet Gynecol 2019;8:2522-7. 